\title{
COMBINING TILT DERIVATIVE FILTERS: NEW APPROACHES TO ENHANCE MAGNETIC ANOMALIES
}

\author{
Fabrício Rodrigues Castro, Saulo Pomponet Oliveira, \\ Jeferson de Souza and Francisco José Fonseca Ferreira
}

ABSTRACT. We extend the concept of two earlier enhancement techniques based on the local phase of the magnetic anomaly, namely the vertical (TDR) and horizontal (TDX) tilt angles, which are defined by the inverse tangent of ratios involving the total horizontal gradient and the vertical derivative. These filters are useful to locate both shallow and deep sources, because they equalize the signal amplitudes. The proposed approach is based on the addition and subtraction of TDR and TDX. The TDR+TDX filter produces constant values over the causative bodies, while TDR-TDX generates peaks over the center of bodies and is constant out of them. By applying the proposed techniques to synthetic and aeromagnetic data we show that they locate more clearly the centers and edges of the sources in comparison to TDR and TDX, respectively. The combined filters have essentially the same computational cost as TDR and TDX and can replace them as auxiliary interpretation tools.

Keywords: qualitative methods, local phase filters, aeromagnetic data.

RESUMO. Estendemos o conceito de duas técnicas de realce baseadas na fase local da anomalia magnética: as inclinações do sinal analítico (TDR) e do gradiente horizontal total (TDX), definidos pelo arco tangente de razões envolvendo o gradiente horizontal total e a derivada vertical. Estes filtros são úteis para localizar tanto fontes rasas quanto profundas. 0 método proposto baseia-se na adição e subtração dos filtros TDR e TDX. 0 filtro TDR+TDX produz valores constantes sobre as fontes causadoras, enquanto que o TDR-TDX produz picos sobre o centro dos corpos e é constante onde fontes causadoras não são verificadas. Aplicando as técnicas propostas aos dados sintéticos e reais mostra-se que elas localizam mais claramente os centros e as bordas dos corpos em comparação com o TDR e 0 TDX, respectivamente. Os filtros combinados têm essencialmente o mesmo custo computacional dos filtros originais, TDR e TDX, e podem substituí-los como ferramentas de interpretação.

Palavras-chave: métodos qualitativos, filtros de fase local, dados aeromagnéticos.

Universidade Federal do Paraná, Graduate Program in Geology and Laboratory for Research in Applied Geophysics, R. Francisco Heráclito dos Santos, 100, Building VI, 81531-980, P.0. Box 19045, Curitiba-PR, Brazil -E-mails: fcastrogeof@gmail.com, saulopo@ufpr.br, jdesouza@ufpr.br, francisco.ferreira@ufpr.br 


\section{INTRODUCTION}

Enhancement methods based on first-order derivatives of gravity and magnetic data are commonly employed to locate edges and centers of causative sources. These techniques are robust in the sense that they can cope with low-quality data, and require low computational effort (Pilkington \& Tschirhart, 2017). Some traditional methods of this class are the analytic signal amplitude (Nabighian, 1972, 1974; Roest et al., 1992) and the total horizontal gradient (Cordell \& Grauch, 1985). These methods have been applied to delineate causative sources in aeromagnetic data (Behrendt et al., 1996; Bastani \& Pedersen, 2001), besides being used as ingredients to develop other filters (Wijns et al., 2005; Cooper, 2009; Ferreira et al., 2013).

Later on, several methods have resorted to normalization in order to balance low and high amplitudes due to shallow and deep sources, respectively. Among these, we focus on local phase filters such as Tilt Angle (Miller \& Singh, 1994), Theta Map (Wijns et al., 2005), and Horizontal Tilt Angle (Cooper \& Cowan, 2006). These filters have been extended to higher-order derivatives as well (Verduzco et al., 2004; Ferreira et al., 2013).

It is well known that some of these methods are equivalent to each other (Pilkington \& Tschirhart, 2017). In particular, Ferreira et al. (2013) observed that $|T D R|=T H$, as well as $|T D R|=$ $\pi / 2-T D X$. In this work we explore the latter relation, which grants special properties to two particular combinations of these filters: TDR+TDX and TDR-TDX. Even though TDR and TDX have shown to be useful tools for geophysical mapping (Oruç \& Selim, 2011; Jordan et al., 2013), these methods do not clearly indicate the boundaries of interfering sources (Zuo et al., 2018).

As we shall see next, TDR+TDX represents an improvement over TDX in the sense that its maximum values are located not only near the edges of the sources, but over the whole sources, resulting in a plateau over them. Likewise, TDR-TDX not only produces a peak over the center of the bodies as TDR, but also generates a plateau over the regions in absence of sources. The plateaus provided by these combined techniques render the potential field easier to interpret.

\section{METHODOLOGY}

Let us recall that the TDR and TDX filters are respectively defined as follows:

$$
T D R=\tan ^{-1}\left(\frac{M_{z}}{M_{h}}\right)
$$

and

$$
T D X=\tan ^{-1}\left(\frac{M_{h}}{\left|M_{z}\right|}\right),
$$

where $M_{z}$ and $M_{h}$ are vertical and total horizontal derivatives of the anomaly $M$. Both formulas equalize the field responses due to the characteristics of the arctangent, whose limits range from $-\pi / 2$ to $\pi / 2$. Moreover, since $\left|\tan ^{-1}(x)\right|=\tan ^{-1}(|x|)$, it follows that

$$
|T D R|=\tan ^{-1}\left(\frac{\left|M_{z}\right|}{M_{h}}\right)=\cot ^{-1}\left(\frac{M_{h}}{\left|M_{z}\right|}\right),
$$

thus, $\tan (T D X)=\cot (|T D R|)$. If $M_{z}=0$, then $T D X=\pi / 2$ and $|T D R|=0$, i.e., $|T D R|=\pi / 2-T D X$. Otherwise, since

$$
\tan (T D X)-\cot (|T D R|)=\frac{\cos (T D X+|T D R|)}{\cos (T D X) \sin (|T D R|)}
$$

and $\tan (T D X)-\cot (|T D R|)=0$, it follows that $\cos (T D X+|T D R|)=0$, and again $|T D R|=\pi / 2-T D X$. This relation can be written as follows:

$$
\left\{\begin{array}{cll}
T D R+T D X=\frac{\pi}{2}, & \text { if } & T D R>0, \\
T D R-T D X=\frac{-\pi}{2}, & \text { if } & T D R<0 .
\end{array}\right.
$$

Since TDR is positive over a source and negative elsewhere (Miller \& Singh, 1994), it turns out that the combined filter $T D R+T D X$ provides a plateau with value $+\pi / 2$ over the sources, whereas TDR-TDX produces plateaus with value $-\pi / 2$ in regions where sources are not expected.

The TDR+TDX and TDR-TDX filters are implemented within GRAV-MAG SUITE, an open-source MATLABC graphical environment for processing potential field data (Castro et al., 2018). For implementation in Geosoft's Oasis Montaj@ package, we recommend to compute the local phase filters (TDR and TDX) in the "Grid Math Expression Builder" section of "Grid and Image" menu to ensure that all filters will be enclosed in the range $[-\pi / 2, \pi / 2]$.

\section{Synthetic example}

To illustrate the properties of the proposed methods, a synthetic model with three equally-spaced prisms was generated using GRAV-MAG PRISM software (Bongiolo et al., 2013), representing parallel dike-like bodies with different depths to the top (Fig. 1). The model parameters are shown in Table 1. The strength, declination and inclination of the induced field vector are $57000 \mathrm{nT}, 0$, and 90 degrees, respectively, and no remanent magnetization was considered. 


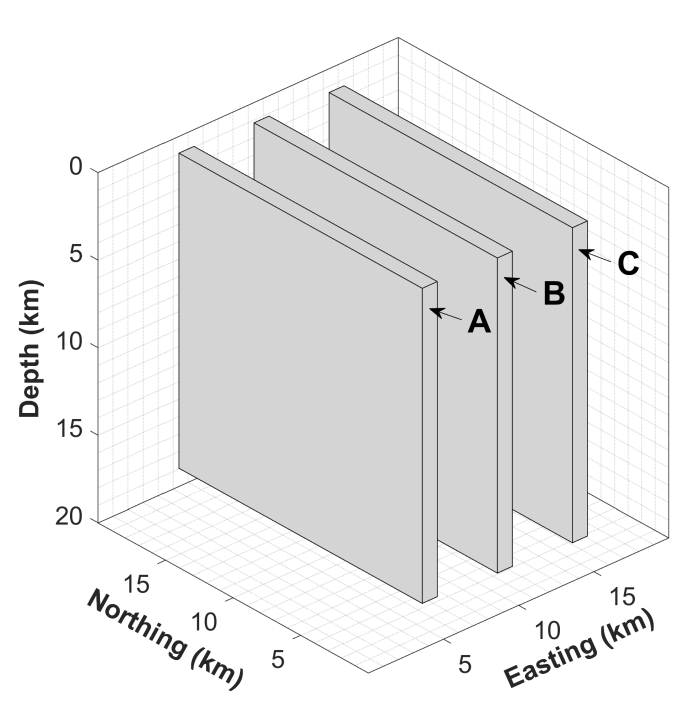

Figure 1 - 3D view of synthetic model.

Table 1 - Geometrical parameters of the synthetic model. X, Y, Z are the coordinates of the prisms.

\begin{tabular}{|c|c|c|c|}
\hline Prism & A & B & C \\
\hline $\mathbf{X}(\mathbf{k m})$ & 5 & 10 & 15 \\
\hline $\mathbf{Y}(\mathbf{k m})$ & 10 & 10 & 10 \\
\hline $\mathbf{Z}(\mathbf{k m})$ & 0.2 & 0.4 & 0.6 \\
\hline Length (km) & 18 & 18 & 18 \\
\hline Width (km) & 1 & 1 & 1 \\
\hline Thickness (km) & 18 & 18 & 18 \\
\hline
\end{tabular}

Figure 2 shows the magnetic anomaly, whereas Figures 3 and 4 show TDR+TDX and TDR-TDX, respectively. As we previously mentioned, the TDR+TDX map (Fig. 3) shows that the plateaus are located over the sources. Likewise, Figure 4 shows that the TDR-TDX values are maximal over the center of each prism and constant out of them.

The profiles at $10 \mathrm{~km}$ are gathered in Figure 5. Figure 5a shows the Total Magnetic Intensity (TMI) profile and Figure $5 \mathrm{~b}$ shows the TMI vertical and horizontal derivatives. Note that TDR-TDX improves TDR by flattening its response away from the sources (Fig. $5 \mathrm{C}$ ). Moreover, while the TDX produces two sharp peaks over the body's edges, the TDR+TDX yields a plateau between them, which makes the source locations more easily identifiable (Fig. 5d).

\section{Field example}

The Ponta Grossa Arch (PGA) is a large uplifted tectonic structure with main axis dipping toward the Paraná Basin interior in a NW direction (Ferreira, 1982). It is composed by four narrow lineaments with approximate extensions of $600 \mathrm{~km}$ and widths varying from $20 \mathrm{~km}$ to $100 \mathrm{~km}$. These lineaments are approximately aligned to the PGA axis and played an important role in the tectonic evolution of Paraná Basin (Algarte, 1972; Vieira, 1973; Ferreira et al., 1981, 1984; Ferreira, 1982; Almeida, 1983, 1986) (Fig. 6).

The study area comprises part of the Guapiara Lineament which defines the northern limit of Ponta Grossa Arch (Ferreira, 1982). This feature is marked by a swarm of NW Eocretaceous diabase dikes and characterizes a crustal suture related to reactivation of Ponta Grossa Arch, due to huge diastrophism during the Mesozoic (Ferreira et al., 1981). This structure was interpreted by Ferreira \& Algarte (1979) as an underfloor expression related to basaltic spills, and alkaline/ultrabasic alkaline vulcanism conditioned by the Guapiara lineament. Figure 7 shows the geological map of study area indicating the diabase dikes (in green) according to Machado Junior (2000).

The aeromagnetic data of study (see location in Fig. 6) were acquired along a north-south flight lines spaced at $500 \mathrm{~m}$ and tie lines at $10 \mathrm{~km}$ with a mean terrain clearance of $150 \mathrm{~m}$ (CPRM, 2011). Figure 8 shows TMl intensity reduced to the pole, whereas Figures 9 to 12 show the corresponding maps of TDR, TDX, $T D R+T D X$ and $T D R-T D X$, respectively.

The TMI anomaly (Fig. 8) shows that the amplitude of some NW-SE anomalies decreases suggesting an increasing depth to top of the corresponding dikes. This behavior is not verified in local phase filters (Figs. 9-12) as the inverse tangent equalizes anomalies related to both deep and shallow sources. On the other hand, these filters may overestimate the lateral limits of deep sources as observed in the synthetic example (Figs. 5c-d).

Note that the dikes contained in the Guapiara Lineament, located at the SW portion of the TMI map (Fig. 8), are blurred by a single anomaly pattern. These dikes can be seen with the TDR filter (Fig. 9) but are best identified in the TDR-TDX map (Fig. 12). The peaks of TDX are difficult to be interpreted as edges without auxiliary filters (e.g., TDR). These peaks are connected by plateaus in TDR+TDX, where no further filtering is needed to avoid ambiguity.

The applicability of TDR $\pm T D X$ is valid for reduced to the pole anomalies and vertical dipping dikes. For low latitudes and subvertical dipping dikes the magnetic anomalies present 

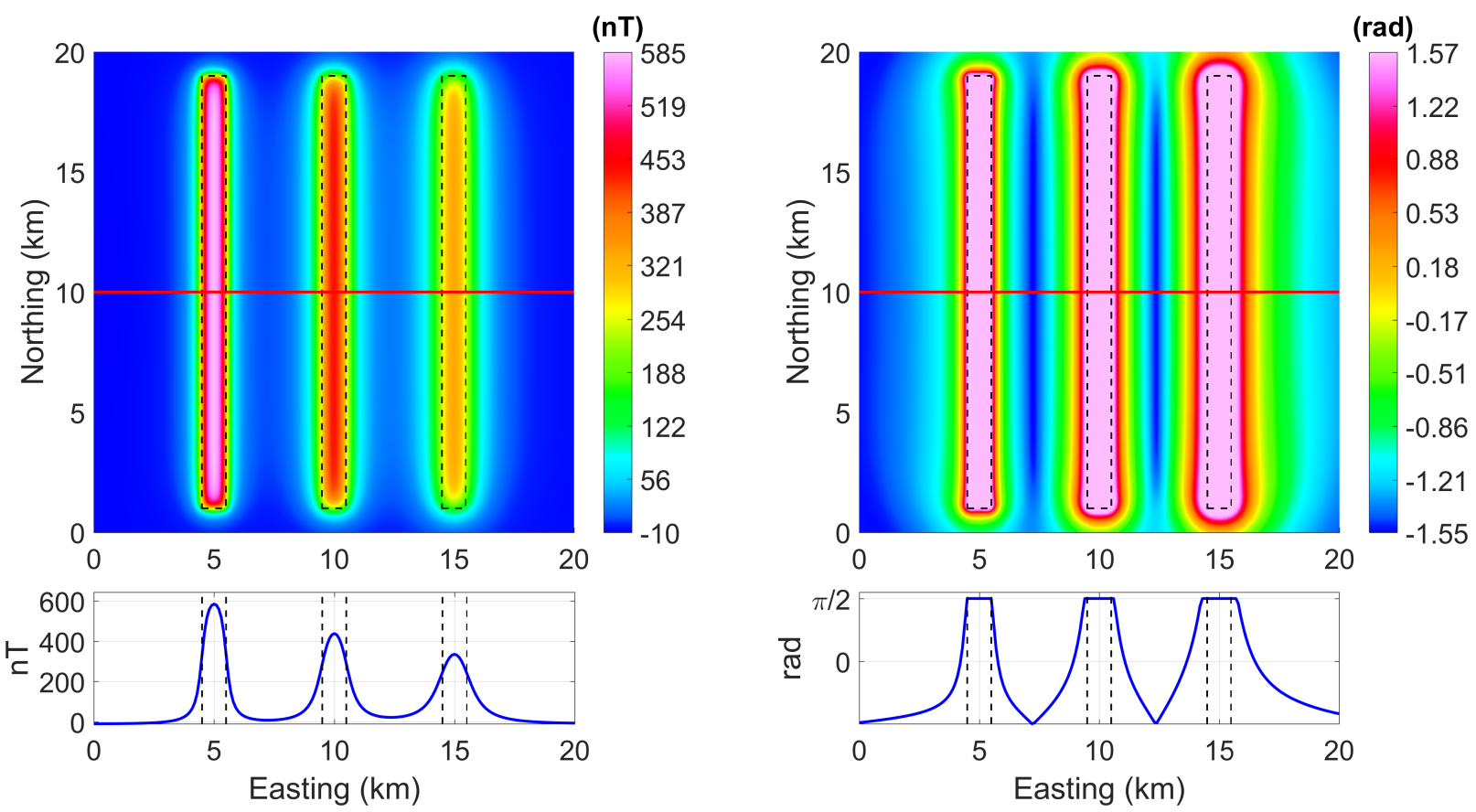

Figure 2 - Total magnetic intensity of the synthetic example with indication of bodies limits (dashed lines) and profile at $\mathrm{y}=10 \mathrm{~km}$ (red line).

Figure 3 - TDR+TDX of the data in Figure 2 with indication of bodies limits (dashed lines) and profile at $\mathrm{y}=10 \mathrm{~km}$.
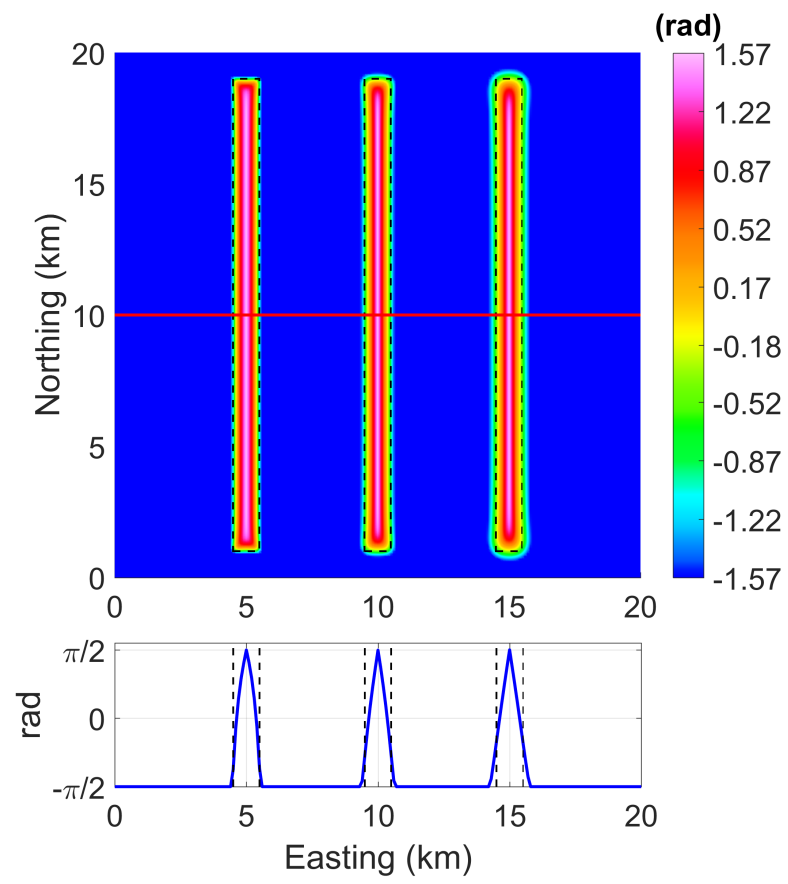

Figure 4 - TDR-TDX of the data in Figure 2 with indication of bodies limits (dashed lines) and profile at $y=10 \mathrm{~km}$. 
a)

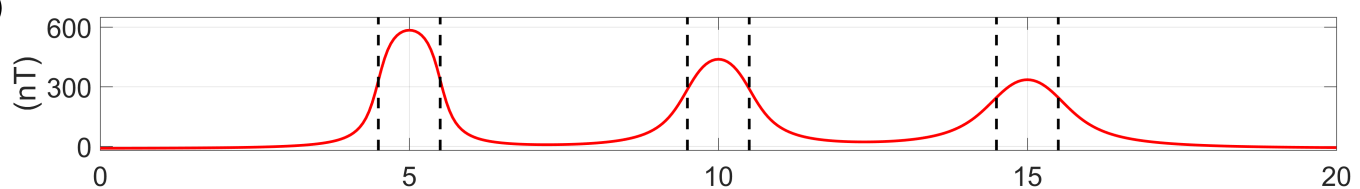

b)

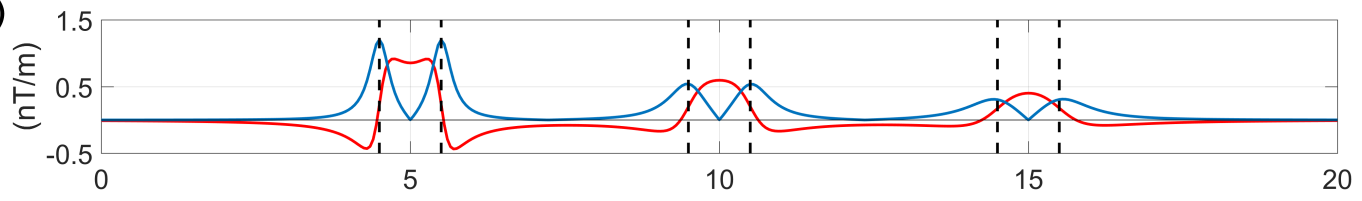

c)
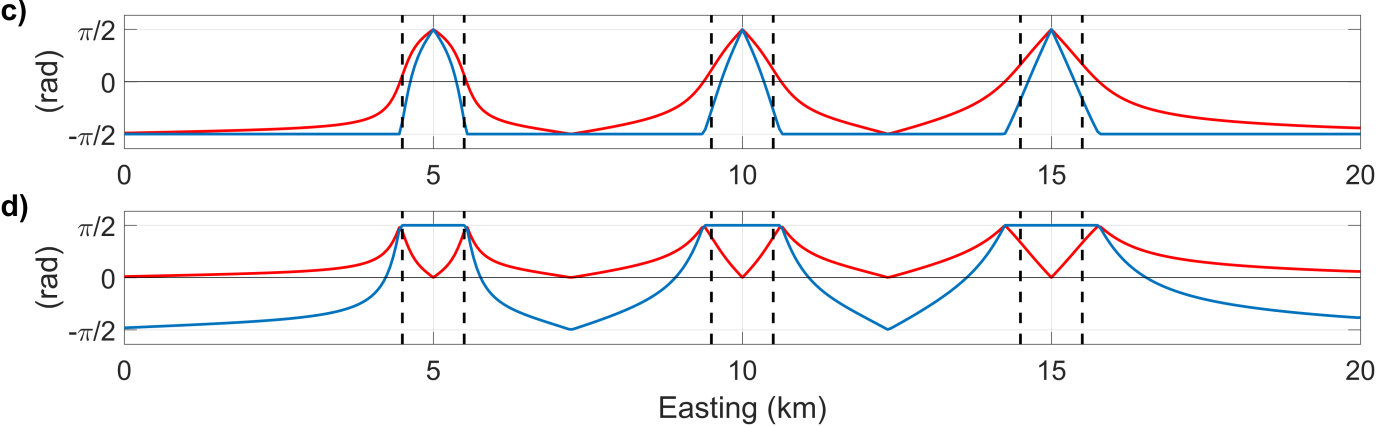

Figure 5 - Profiles at 10km: (a) TMI profile (extracted from Fig. 2); (b) first-order derivatives (red line: Mz and blue line: $|M x|$ ); (c) TDX (red line) and TDR-TDX (blue line); (d) TDR (red line) and TDR+TDX (blue line).

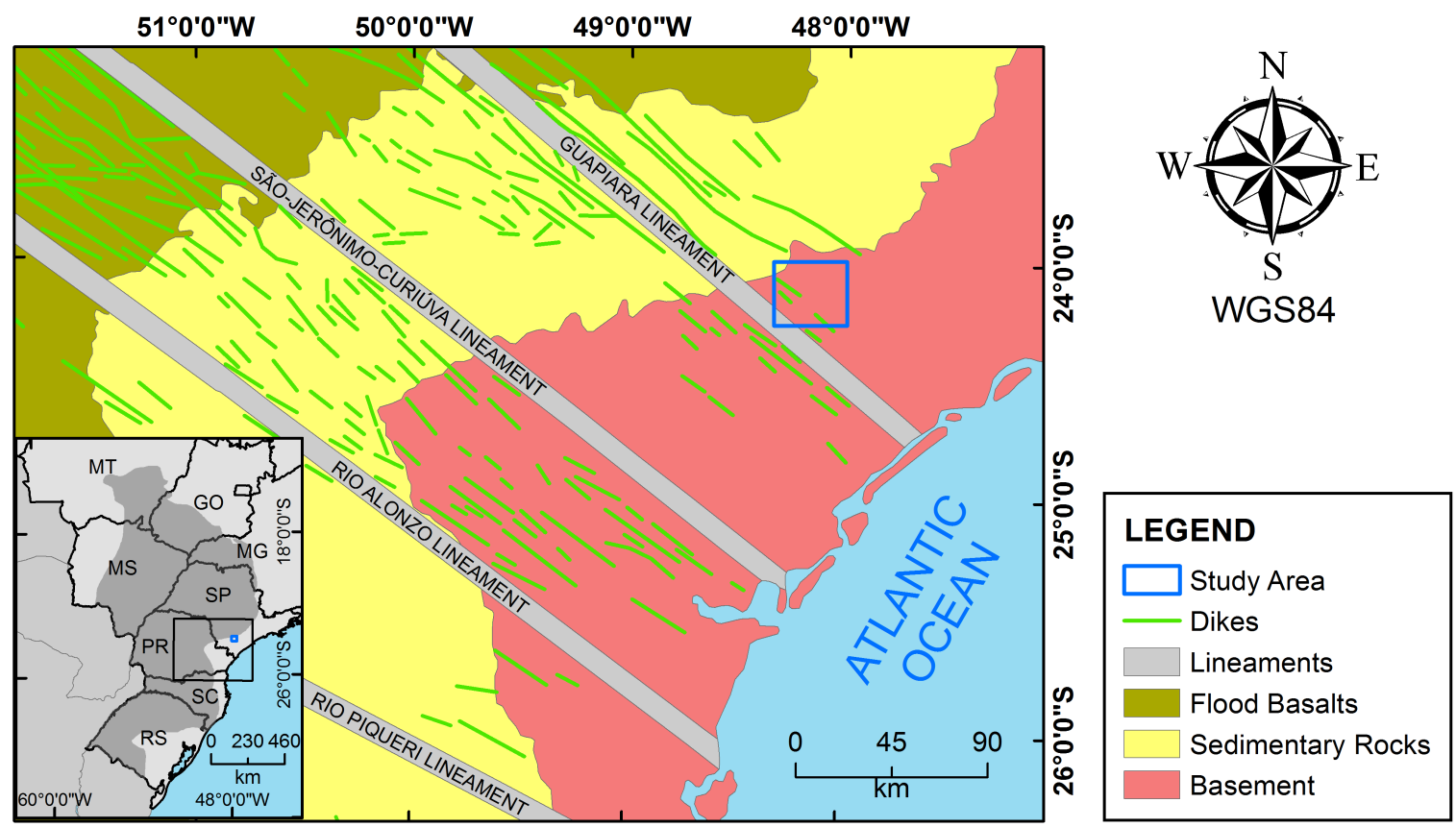

Figure 6 - Sketch map of Ponta Grossa Arch with indication of four lineaments and dike swarm (Ruberti et al., 2005; Gomes et al., 2018) 


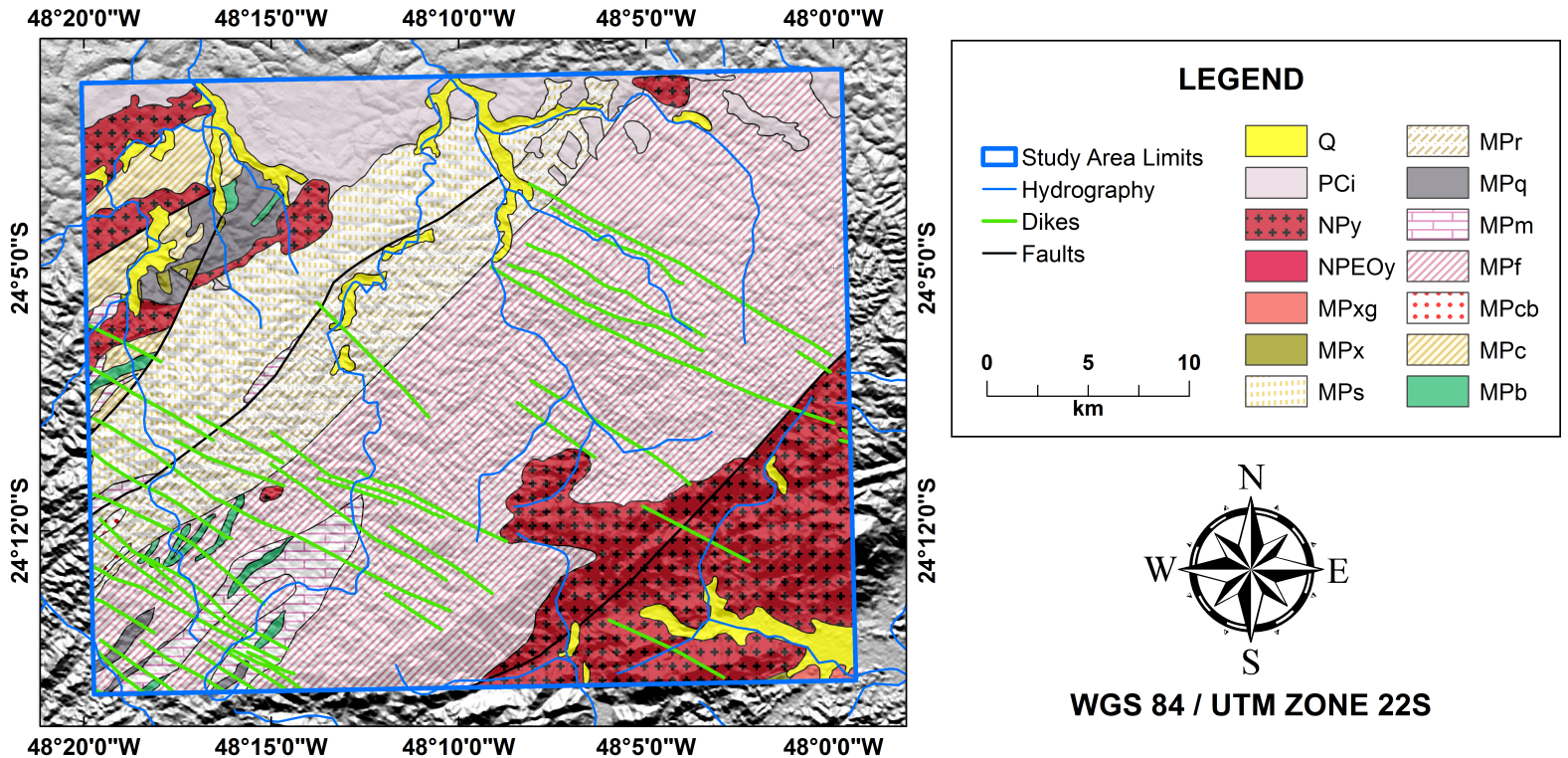

Figure 7 - Geologic map of study area (see location in Fig. 6) listing the main lithotypes and structures over a grey shaded relief. Q (Quaternary deposits); PCi (Carboniferous Permian - Itararé Sub-Group); NPy (Neoproterozoic - Pos-tectonic granites); NPEOy (Neoproterozoic - Polimitic; greywacke, and meta-arkose conglomerates); MPxg (Mesoproterozoic - Micaxists); MPx (Mesoproterozoic - Schists); MPs (Mesoproterozoic - Phyllites); MPr (Mesoproterozoic - Meta-sandstones); MPq (Mesoproterozoic - Quartzite); MPm (Mesoproterozoic - Marbles); MPf (Mesoproterozoic - Meta-rhythmites); MPcb (Mesoproterozoic - Meta-conglomerates and meta-breccias); MPc (Mesoproterozoic - Calcissilictics with phyllite or schist associated); and MPb (Mesoproterozoic - Mafic meta-vulcanics), modified from Machado Junior (2000).

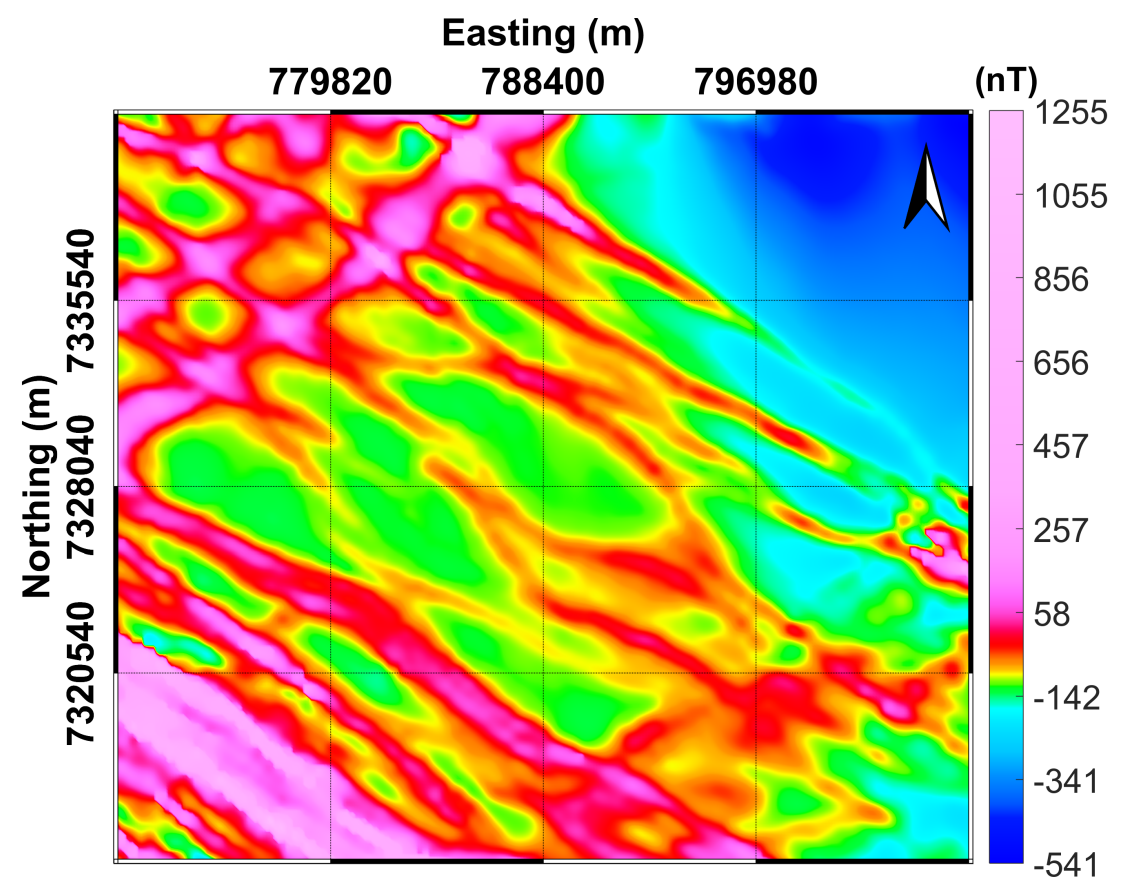

Figure 8 - TMl reduced to the magnetic pole (see location in Fig. 6) 


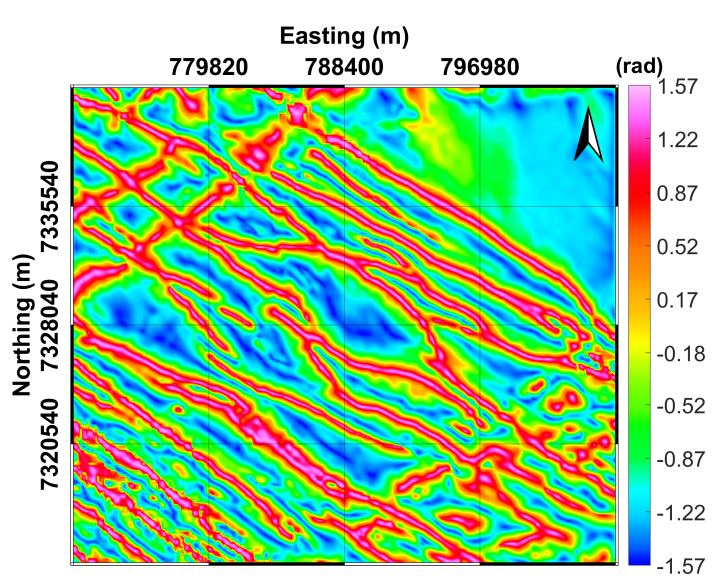

Figure $\mathbf{9}$ - TDR of the data in Figure 8.

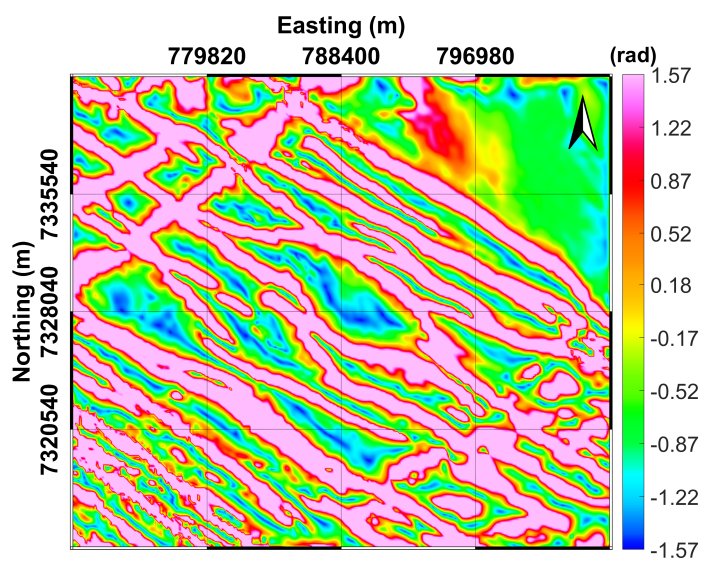

Figure 11 - TDR+TDX of the data in Figure 8.

a dipolar character and the positive peaks do not necessarily correspond to the bodies' horizontal limits. The application of the proposed filters in these situations may result in shifted peaks and plateaus.

\section{CONCLUSIONS}

In this preliminary study, we have verified that simple combinations of well-known tilt derivative filters have shown to improve the focus on the edges and centers of the sources, in both synthetic and field data. As illustrated in the chosen field data (Fig. 8), TDR-TDXflattens out the anomaly in the absence of structures of interest to geological mapping.

The proposed filters naturally inherit some limitations from the primary ones. Both TDR+TDX and TDR-TDX products spread those lateral limits according to increasing depth, for example, for deep sources the limits of body edges will appear greater than actual ones. Low-latitude magnetic anomalies present a dipolar

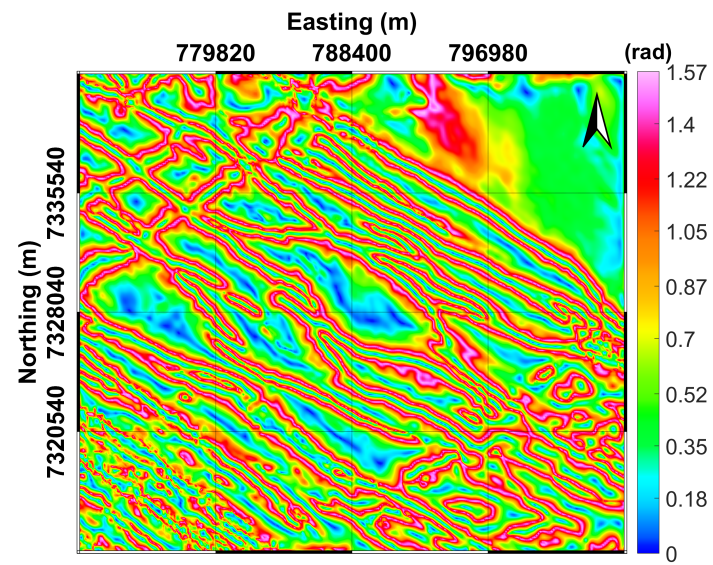

Figure $\mathbf{1 0}$ - TDX of the data in Figure 8.

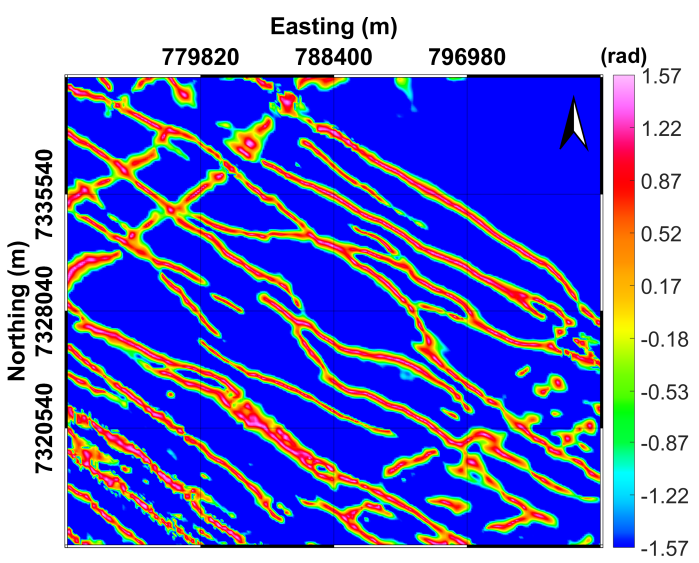

Figure 12 - TDR-TDX of the data in Figure 8.

character that remains after the application of proposed filters, as in typical local phase filters. A similar behavior is noticed on subvertical dipping dikes where dipolarity is also observed.

The idea of combining filters could be applied to other qualitative methods (e.g., second order filters). Moreover, $T D R+T D X$ has great potential in the processing of noisy data. In contrast with $T D R$ and $T D X$, where the sources are identified by peaks which may be confounded with noise, the plateaus over the sources in TDR+TDX could be easily distinguished from those artifacts.

\section{ACKNOWLEDGMENTS}

The authors thank Programa de Pós-Graduação em Geologia UFPR, DS/CAPES, and CNPq (grants 306978/2015-6, 313100/2017-9, and 113897/2018-9) for their financial support. The authors are grateful to Serviço Geológico do Brasil (CPRM) for permission to use the aeromagnetic data. 


\section{REFERENCES}

ALGARTE JP. 1972. A influência dos arqueamentos cratônicos no condicionamento das alcalinas dos Estados de São Paulo e Paraná. In: 26 Congresso Brasileiro de Geologia. Volume 1, SBG, Belém, Brazil.

ALMEIDA FFM. 1983. Relações tectônicas das rochas alcalinas mesozóicas da região meridional da Plataforma Sul-Americana. Revista Brasileira de Geociências, 13(3): 139-158.

ALMEIDA FFM. 1986. Distribuição regional e relações tectônicas do magmatismo pós-paleozóico no Brasil. Revista Brasileira de Geociências, 16(4): 325-349.

BASTANI M \& PEDERSEN LB. 2001. Automatic interpretation of magnetic dike parameters using the analytical signal technique. Geophysics, 66(2): 551-561.

BEHRENDT JC, SALTUS R, DAMASKE D, MCCAFFERTY A, FINN CA, BLANKENSHIP D \& BELL RE. 1996. Patterns of late Cenozoic volcanic and tectonic activity in the West Antarctic rift system revealed by aeromagnetic surveys. Tectonics, 15(3): 660-676.

BONGIOLO ABS, DE SOUZA J, FERREIRA FJF \& DE CASTRO LG. 2013. GRAV_MAG_PRISM: a MATLAB/OCTAVE program to generate gravity and magnetic anomalies due to rectangular prismatic bodies. Brazilian Journal of Geophysics, 31(3): 347-363.

CASTRO FR, OLIVEIRA SP, DE SOUZA J \& FERREIRA FJF. 2018. GRAV-MAG SUITE: An open source MATLAB-based program for processing potential field data. In: VIII Simpósio Brasileiro de Geofísica. Volume 1, SBGf, Pará, Brazil.

COOPER GR. 2009. Balancing images of potential-field data. Geophysics, 74(3): L17-L20.

COOPER GRJ \& COWAN DR. 2006. Enhancing potential field data using filters based on the local phase. Computers \& Geosciences, 32(10): 1585-1591.

CORDELL L \& GRAUCH VJS. 1985. Mapping Basement Magnetization Zones from Aeromagnetic Data in the San Juan Basin, New Mexico. doi: 10.1190/1.0931830346.ch16. URL https://library.seg.org/doi/abs/ 10.1190/1.0931830346.ch16.

CPRM. 2011. Projeto Aerogeofísico Paraná-Santa Catarina. Technical report. Serviço Geológico do Brasil. Brazil.

FERREIRA FJF. 1982. Integração de dados aeromagnéticos e geológicos: configuração e evolução tectônica do Arco de Ponta Grossa. M.Sc Dissertation. Universidade de São Paulo. Brazil. 169 pp.

FERREIRA FJF \& ALGARTE JP. 1979. 0 comportamento aeromagnético-cintilométrico das principais rochas alcalinas dos Estados de São Paulo e Paraná. In: 2 Simpósio Regional de Geologia. Volume 2, Brazil, p. 195-208.
FERREIRA FJF, DAITX EA \& MORAES MC. 1984. Nova manifestação do magmatismo mesozóico associada ao Arco de Ponta Grossa: 0 complexo gabróide Barra do Estrela. In: 33 Congresso Brasileiro de Geologia. Volume 1, SBG, Brazil.

FERREIRA FJF, DE SOUZA J, DE B E S BONGIOLO A \& DE CASTRO LG. 2013. Enhancement of the total horizontal gradient of magnetic anomalies using the tilt angle. Geophysics, 78(3): J33-J41.

FERREIRA FJF, MORAES RAV, FERRARI MP \& VIANNA RB. 1981. Contribuição ao estudo do Alinhamento Estrutural de Guapiara. In: Simpósio Regional de Geologia, 3., Curitiba, Brazil. p. 226-240.

GOMES CB, AZZONE RG, RUBERTI E, VASCONCELOS PMD, SATO K \& ROJAS GEE. 2018. New age determinations for the Banhadão and Itapirapuã complexes in the Ribeira Valley, southern Brazil. Brazilian Journal of Geology, 48(2): 403-414.

JORDAN TA, FERRACCIOLI F, ROSS N, CORR HF, LEAT PT, BINGHAM RG, RIPPIN DM, LE BROCQ A \& SIEGERT MJ. 2013. Inland extent of the Weddell Sea Rift imaged by new aerogeophysical data. Tectonophysics, 585: $137-160$

MACHADO JUNIOR DDL. 2000. Condicionantes estruturais e contexto tectônico do alinhamento de Guapiara. Ph.D. thesis. Universidade de São Paulo, Brazil. 143 pp.

MILLER HG \& SINGH V. 1994. Potential field tilt-a new concept for location of potential field sources. Journal of Applied Geophysics, 32(2-3): 213-217.

NABIGHIAN MN. 1972. The analytic signal of two-dimensional magnetic bodies with polygonal cross-section: its properties and use for automated anomaly interpretation. Geophysics, 37(3): 507-517.

NABIGHIAN MN. 1974. Additional comments on the analytic signal of two-dimensional magnetic bodies with polygonal cross-section. Geophysics, 39(1): 85-92.

ORUÇ B \& SELIM HH. 2011. Interpretation of magnetic data in the Sinop area of Mid Black Sea, Turkey, using tilt derivative, Euler deconvolution, and discrete wavelet transform. Journal of Applied Geophysics, 74(4): 194-204.

PILKINGTON M \& TSCHIRHART V. 2017. Practical considerations in the use of edge detectors for geologic mapping using magnetic data. Geophysics, 82(3): J1-J8. doi: 10.1190/ge02016-0364.1. URL https: //doi.org/10.1190/ge02016-0364.1.

ROEST WR, VERHOEF J \& PILKINGTON M. 1992. Magnetic interpretation using the 3-D analytic signal. Geophysics, 57(1): 116-125. doi: 10.1190/1.1443174. URL https://doi.org/10.1190/1.1443174.

RUBERTIE, GOMES CB \& COMIN-CHIARAMONTI P. 2005. The alkaline magmatism from the Ponta Grossa Arch. Brazilian Platform. Edusp, São Paulo, Brazil. 
VERDUZCO B, FAIRHEAD JD, GREEN CM \& MACKENZIE C. 2004. New insights into magnetic derivatives for structural mapping. The Leading Edge, 23(2): 116-119.

VIEIRA AJ. 1973. Geologia do centro e nordeste do Paraná e centro-sul de São Paulo. In: Congresso Brasileiro de Geologia, 27., Aracaju, Brazil. p. 259-277.

Recebido em 22 setembro, 2018 / Aceito em 21 novembro, 2018

Received on September 22, 2018 / accepted on November 21, 2018
WIJNS C, PEREZ C \& KOWALCZYK P. 2005. Theta map: edge detection in magnetic data. Geophysics, 70(4): L39-L43.

ZUO B, HU X, LIU S \& GENG M. 2018. Delineation of overlapping magnetic field source boundaries with a 3-D multi-layer convolution model. Journal of Applied Geophysics, 150: 74-83. 